\title{
Allergic and immunological aspects of therapy with cefotaxime and other cephalosporins*
}

\author{
A. L. de Weck and C. H. Schneider \\ Institute for Clinical Immunology, Inselspital \\ 3010 Bern, Switzerland
}

\begin{abstract}
Immunogenicity and allergenicity studies in rodents show that cefotaxime and cefuroxime are less immunogenic than benzylpenicillin or the semisynthetic penicillins. Cross-reactions of these antibiotics with benzylpenicilloyl-specific animal and human IgE antibodies appear minimal. Some cross-reactivity at the level of cell-mediated allergic reactions may, however, be expected.
\end{abstract}

\section{Introduction}

Allergic and immune reactions remain one of the major side-effects of $\beta$-lactam antibiotics. However, as experience with natural and semisynthetic penicillins has shown, there may be variations in the incidence, the severity and also the clinical forms of allergic reactions to $\beta$-lactam antibiotics according to their structure, chemical reactivity, dosage and mode of administration. Therefore, the development of a new $\beta$ lactam antibiotic raises the following questions: (1) Is this new antibiotic potentially
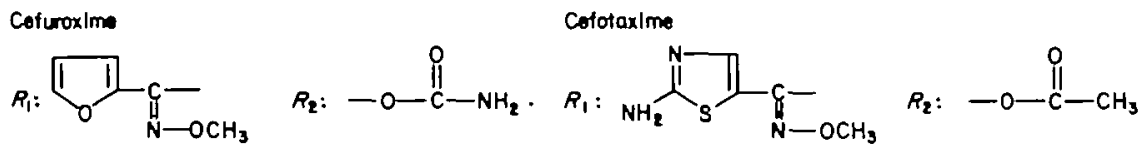

Cepholexln

$R_{\text {i }}$

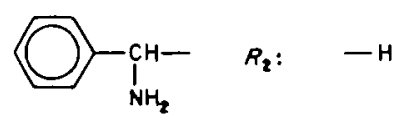

Cephaboridine
Copholothin
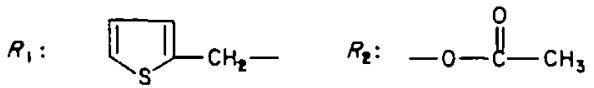<smiles></smiles>

Figure 1. Side-chain structures and generic names of cephalosporins and some abbreviations.

\footnotetext{
*Abbreviations used: CEFOX, cefuroxime; CEPHALEX, cephalexin; CEPHOR, cephaloridine; CETAX, cefotaxime; CEPHALOT, cephalothin; BPO, benzylpenicilloyl; BPO-FLYS, $N^{*}$-formyl- $N^{*}$-benzylpenicilloylL-lysine; BPNCO, benzylpenicilloic acid; BPN, benzylpenicillin; AMPIC, ampicillin; PLL, poly-L-lysine; BGG, bovine gamma globulin; HSA, human serum albumin. 
sensitizing as the other drugs currently on the market? (2) Will this new penicillin or cephalosporin cross-react with other already established $\beta$-lactam antibiotics and correspondingly will it elicit allergic reactions in patients already hypersensitive to penicillin?

This brief presentation aims to answer these questions as far as cefotaxime (CETAX) and another cephalosporin of similar side-chain structure, cefuroxime (CEFOX) are concerned (Figure 1).

\section{Immunogenicity}

The capacity of $\beta$-lactam antibiotics to evoke immune responses and to sensitize has been classically linked, as for other sensitizing low-molecular weight chemicals, to their capacity to form covalent bonds with soluble and membrane proteins. Accordingly, chemical reactivity with various amino acids, peptides or proteins has sometimes been taken as a measure of the expected immune reactivity. Indeed, aminolysis rate among penicillins is variable and seems to correlate to some extent with the capacity to sensitize rodents. While the reactivity of penicillins to form the major penicilloyl antigenic determinant is well known, the corresponding immunochemistry of cephalosporins is more complex and has been less extensively studied (Dewdney, 1977). Studies on the chemical reactivity of cephalosporins with amines or proteins at various $\mathrm{pH}$ have suggested that cephalosporoyl amide, the equivalent of the penicilloyl haptenic group is of low stability and may decompose to more simple, e.g penaldate, derivatives.

Tabie I. Comparative immunogenicity of CEFOX-BGG conjugate, CEFOX, CETAX, CEPHOR and penicillins

\begin{tabular}{|c|c|c|c|c|}
\hline Immunization with & $\begin{array}{l}\text { Serum teste } \\
\text { Serum from day }\end{array}$ & $\begin{array}{l}\text { for PCA } \\
\text { Tested with }\end{array}$ & & \\
\hline $\begin{array}{l}\text { CEFOX-BGG } \\
1 \mu \mathrm{g} \text { in } \mathrm{Al}(\mathrm{OH})_{3} \text { on } \\
\text { days } 0,21,42,63\end{array}$ & 70 & $\begin{array}{l}\text { CEFOX-PLL } \\
\text { CEFOX-HSA } \\
\text { BPO-PLL } \\
\text { CEPHOR-PLL }\end{array}$ & $\begin{array}{r}10 / 10 \\
10 / 10 \\
0 / 10 \\
10 / 10\end{array}$ & $\begin{array}{l}(>1: 10000) \\
(>1: 10000) \\
(1: 10) \\
(1: 400)\end{array}$ \\
\hline \multirow[t]{2}{*}{$\begin{array}{l}\text { CEFOX } \\
1 \text { mg in } \mathrm{Al}(\mathrm{OH})_{3} \text { on } \\
\text { days } 0,21,42,63,84\end{array}$} & 49 & $\begin{array}{l}\text { CEFOX-PLL } \\
\text { CEPHOR-PLL } \\
\text { BPO-PLL }\end{array}$ & $\begin{array}{l}0 / 8 \\
0 / 8 \\
0 / 8\end{array}$ & $\begin{array}{l}(1: 10) \\
(1: 10) \\
(1: 10)\end{array}$ \\
\hline & 91 & $\begin{array}{l}\text { CEFOX-PLL } \\
\text { CEPHOR-PLL } \\
\text { BPO-PLL }\end{array}$ & $\begin{array}{l}0 / 8 \\
0 / 8 \\
0 / 8\end{array}$ & $\begin{array}{l}(1: 10) \\
(1: 10) \\
(1: 10)\end{array}$ \\
\hline $\begin{array}{l}\text { CEPHOR } \\
1 \text { mg in } \mathrm{Al}(\mathrm{OH})_{3} \text { on } \\
\text { days } 0,21,42,63,84\end{array}$ & 49 & $\begin{array}{l}\text { CEFOX-PLL } \\
\text { CEPHOR-PL } \\
\text { BPO-PLL }\end{array}$ & $\begin{array}{l}0 / 8 \\
0 / 8 \\
0 / 8\end{array}$ & $\begin{array}{l}(1: 10) \\
(1: 10) \\
(1: 10)\end{array}$ \\
\hline $\begin{array}{l}\text { CETAX } \\
1 \mathrm{mg} \text { in } \mathrm{Al}(\mathrm{OH})_{3} \text { on } \\
\text { days } 0,21,42,63,84\end{array}$ & 49 & $\begin{array}{l}\text { CEFOX-PLL } \\
\text { CEPHOR-PL } \\
\text { BPO-PLL }\end{array}$ & $\begin{array}{l}0 / 8 \\
0 / 8 \\
0 / 8\end{array}$ & $\begin{array}{l}(1: 10) \\
(1: 10) \\
(1: 10)\end{array}$ \\
\hline Benzylpenicillin (BPN) & 49 & BPO-PLL & $17 / 20$ & $(1: 200)$ \\
\hline Ampicillin (AMPI) & 49 & AMPI-PLL & $3 / 8$ & $(1: 20)$ \\
\hline
\end{tabular}


Cephalosporin determinants having undergone such transformation retain the sidechain $\left(R_{1}\right)$ but lack the dihydrothiazine ring (Hamilton-Miller, Newton \& Abraham, 1970; Steinberger \& Wiedermann, 1970).

Upon repeated injection of guinea pigs with penicillins either with various adjuvants or without adjuvant (thus mimicking therapeutic administration) large variations in the capacity to sensitize have been observed. While benzylpenicillin is regularly sensitizing producing antibodies of benzylpenicilloyl specificity, antibody production to, e.g. ampicillin, appears much less constant. We have been unable under experimental conditions to achieve sensitization either by cefotaxime or cefuroxime. However, when preformed protein conjugates are used for immunization high grade sensitization to the cephalosporins is regularly achieved with high titres of antibodies as detected by passive cutaneous anaphylaxis (Tables I and II). As studied in some detail in the penicillin

Table II. Active and passive anaphylactic reactions in animals immunized with CEPHOX-BGG

\begin{tabular}{|c|c|c|c|c|c|c|c|}
\hline $\begin{array}{l}\text { Guinea pig* } \\
\text { no. }\end{array}$ & $\begin{array}{l}\text { CEFOX } † \\
1: 10\end{array}$ & $\begin{array}{c}\text { CEFOX- } \\
\text { HSA } \\
1: 10000\end{array}$ & $\begin{array}{l}\text { CA elicite } \\
\text { BPO- } \\
\text { FLYS } \\
1: 10\end{array}$ & $\begin{array}{r}\text { BPO } \\
1: 10\end{array}$ & $\begin{array}{c}\text { BPNCO } \\
1: 10\end{array}$ & $\begin{array}{l}\text { BPO- } \\
\text { PLL } \\
1: 10\end{array}$ & $\begin{array}{l}\text { Active shock } \\
\text { CEFOX } 25 \mathrm{mg} \\
\text { i.v. }\end{array}$ \\
\hline 2133 & $434 \ddagger$ & 78 & 277 & 0 & 0 & 0 & death \\
\hline 2134 & 490 & 103 & 0 & 0 & 0 & 0 & death \\
\hline 2135 & 706 & 160 & 0 & 0 & 0 & 0 & death \\
\hline 2136 & 379 & 314 & 0 & 0 & 0 & 0 & severe shock \\
\hline 2137 & 706 & 298 & 0 & 0 & 0 & 0 & death \\
\hline 2138 & 542 & 314 & 0 & 0 & 0 & 0 & not done \\
\hline 2139 & 510 & 356 & 0 & 0 & 0 & 0 & death \\
\hline 2140 & 672 & 356 & 0 & 0 & 0 & 0 & death \\
\hline 2141 & 618 & 177 & 0 & 0 & 0 & 0 & death \\
\hline 2142 & 370 & 490 & 0 & 0 & 0 & 0 & severe shock \\
\hline
\end{tabular}

*Ten guinea pigs immunized with $1 \mu \mathrm{g}$ CEFOX-BGG in $\mathrm{Al}(\mathrm{OH})_{3}$; PCA with serum from day 105, elicitation of shock on day 109.

†Elicitor doses were $25 \mathrm{mg}$ for monovalent compounds and $1 \mu \mathrm{mol}$ hapten for conjugates. The ratios given indicate serum dilutions.

$\ddagger$ Blue reaction in $\mathrm{mm}^{2}$.

system, antibodies produced against the penicilloyl antigenic determinant may be divided into three categories: (a) those specific for the side-chain; (b) those specific for the thiazolidine nucleus; (c) those specific for the whole hapten. As will be discussed later, it appears that antibodies raised by cefuroxime-protein conjugates are to a large extent specific for the cefuroxime side-chain as very little cross-reactivity with other penicillins and/or cephalosporins could be demonstrated (Figure 2).

Can one predict the sensitizing capacity and the expected incidence of allergic reactions in man from sensitizing experiments in guinea pigs or mice? There is, as yet, no definite answer to the question. It is striking, however, that the poorer antibody response to ampicillin in guinea pigs coincides with the fact that immediate-type reactions to ampicillins are also much rarer in man than those to benzylpenicillin. As far as the cephalosporins are concerned, the majority of studies performed thus far indicate that the incidence of allergic reactions is low despite a dosage which is often higher than used in penicillin therapy. 


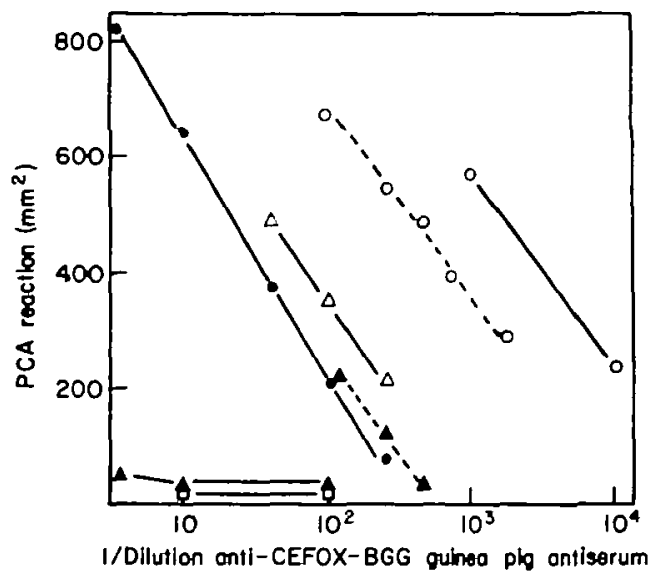

Figare 2. Elicitation of PCA in guinea pigs sensitized with anti-CEFOX-BGG guinea pig antiserum by means of 0.1 $\mu \mathrm{mol}$ CEFOX-HSA (O-O); $0.1 \mu \mathrm{mol}$ CEFOX-PLL (O- - $-\mathrm{O}) ; 25 \mathrm{mg}$ CEFOX $(-\longrightarrow) ; 25 \mathrm{mg}$ CETAX $(\Delta-\Delta) ; 10 \mathrm{mg}$ CEPHOR $(\Delta-\Delta) ; 0-1 \mu \mathrm{mol}$ CEPHOR-PLL $(\Delta-\Delta)$; 0.1 $\mu \mathrm{mol}$ BPO-PLL $(\square-\square)$.

\section{Allergenicity and cross-reactivity}

The allergenicity, i.e. the capacity to elicit allergic reactions in already sensitized individuals and the cross-reactivity of a new cephalosporin are obviously of interest in order to assess the risks of its potential use in a population which has been treated for many years by penicillins or other cephalosporins. It is generally estimated that 3 to $5 \%$ of the individuals in industrialized countries are allergic to penicillins.

A first indication about the cross-reactivity and potential allergenicity of the new cephalosporins cefotaxime and cefuroxime may be gained from studying the crossreactivity among antibodies raised in rodents by the corresponding cephalosporin- or penicilloyl-protein conjugates. In guinea pigs with very high titres of antibodies raised by cefuroxime-protein conjugates, there was practically no reaction with benzylpenicillin and benzylpenicilloyl-protein antigens (Table III). Even with other cephalosporins such as cephaloridine, cephalothin and cephalexin, only a very low grade of crossreactivity was observed suggesting that the bulk of the antibodies raised by cefuroxime-protein conjugates is directed against the side-chain and not against the entire cephalosporoyl moiety. The observation that cefotaxime is definitely cross-reacting with anti-bodies raised against cefuroxime would also fit into this picture since the respective $R_{1}$ side-chains of the two antibiotics share at least one structural element.

The antibody response obtained in guinea pigs against a cefotaxime-HSA conjugate has not yet reached full strength. Nevertheless it is obvious that at least a weak crossreaction in PCA with CEFOX-PLL is elicitable; on the other hand the lack of crossreactivity with BPO-PLL is already apparent (Table IV).

The almost complete absence of cross-reactivity in human immediate-type allergy was confirmed by studies on the IgE penicilloyl-specific antibodies of patients allergic to penicillin. Among 22 individuals showing high levels of BPO-specific IgE antibodies demonstrated by the RAST test, no IgE antibodies against the cefuroxime group were detected (Table V). The same result is obtained from RAST inhibition experiments where BPO-specific RAST binding can virtually not be inhibited by cefotaxime or cefuroxime (Figure 3). 


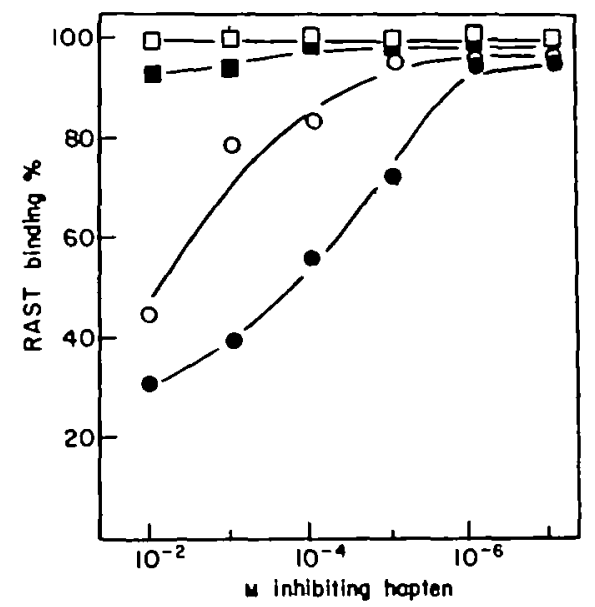

Figure 3. Inhibition of RAST (BPO-specific human IgE-binding to BPO-HSA-sepharose) by penicillin and cephalosporin haptens including CETAX ( $\square-\square)$ CEFOX ( $\square-\square)$; BPN (O-O); BPO-FLYS (O-O).

Table III. Elicitation of PCA reactions by cephalosporins with various antisera induced by BPOBGG and CEFOX-BGG

\begin{tabular}{|c|c|c|c|}
\hline Antiserum used for PCA & Elicitor & Result* & \\
\hline $\begin{array}{l}\text { Guinea pig anti-CEFOX-BGG } \\
\text { (immuniz in } \mathrm{Al}(\mathrm{OH})_{3} \text { ) }\end{array}$ & $\begin{array}{l}\text { CEFOX-HSA } \\
\text { CEFOX-PLL } \\
\text { CEFOX } \\
\text { CEPHOR-PLL } \\
\text { CEPHOR } \\
\text { CEPHALOT } \\
\text { CEPHALEX } \\
\text { CETAX } \\
\text { BPO-PLL }\end{array}$ & $\begin{array}{l}+++ \\
+++ \\
+ \\
++ \\
+ \\
- \\
++ \\
+\end{array}$ & $\begin{array}{l}(1: 10000) \\
(1: 10000) \\
(1: 200) \\
(1: 400) \\
(1: 10) \\
(1: 5) \\
(1: 5) \\
(1: 400) \\
(1: 10)\end{array}$ \\
\hline $\begin{array}{l}\text { Guinea pig anti-BPO-BGG } \\
\text { (immuniz. in } \mathrm{Al}(\mathrm{OH})_{3} \text { ) }\end{array}$ & $\begin{array}{l}\text { BPO-PLL } \\
\text { CEFOX-PLL } \\
\text { CEFOX } \\
\text { CEPHOR-PLL } \\
\text { CEPHOR } \\
\text { CEPHALOT } \\
\text { CEPHALEX } \\
\text { CETAX }\end{array}$ & $\begin{array}{l}+++ \\
++ \\
- \\
++ \\
- \\
- \\
-\end{array}$ & $\begin{array}{l}(1: 10000) \\
(1: 100) \\
(1: 5) \\
(1: 200) \\
(1: 5) \\
(1: 5) \\
(1: 5) \\
(1: 5)\end{array}$ \\
\hline $\begin{array}{l}\text { Guinea pig anti-BPO-BGG } \\
\text { (immuniz, in CFA) }\end{array}$ & $\begin{array}{l}\text { CEFOX } \\
\text { CEPHOR } \\
\text { CETAX }\end{array}$ & $\begin{array}{l}- \\
-\end{array}$ & $\begin{array}{l}(1: 5) \\
(1: 5) \\
(1: 5)\end{array}$ \\
\hline $\begin{array}{l}\text { Rabbit anti-BPO-BGG } \\
\text { (immuniz. in CFA) }\end{array}$ & $\begin{array}{l}\text { CEFOX } \\
\text { CEPHOR } \\
\text { CETAX }\end{array}$ & $\begin{array}{l}- \\
- \\
-\end{array}$ & $\begin{array}{l}(1: 5) \\
(1: 5) \\
(1: 5)\end{array}$ \\
\hline
\end{tabular}

"In ( hend point PCA titre or for negatives, lowest serum dilution tested. 
Tabłe IV. Evaluation by PCA of CETAX-sensitized guinea pigs*

\begin{tabular}{lcccc}
\hline \multicolumn{1}{c}{ Elicitor } & Dose & \multicolumn{3}{c}{ Fraction of animals affording positive sera at } \\
& & $1: 10$ & $1: 100$ & $1: 1000$ \\
\hline CETAX-PLL & $0.1 \mu \mathrm{mol}$ & $8 / 8$ & $6 / 8$ & $4 / 8$ \\
CEFOX-PLL & $0-1 \mu \mathrm{mol}$ & $1 / 8$ & ND & ND \\
BPO-PLL & $0-1 \mu \mathrm{mol}$ & $0 / 8$ & $0 / 8$ & $0 / 8$ \\
CETAX & $1 \mathrm{mg}$ & $2 / 8$ & ND & ND \\
CETAX & $0-1 \mathrm{mg}$ & $1 / 8$ & ND & ND \\
CEFOX & $1 \mathrm{mg}$ & $2 / 8$ & ND & ND \\
\hline
\end{tabular}

-Eight guines pigs immunized with $1 \mu \mathrm{g}$ CETAX-HSA in Al(OH) $)_{3}$ PCA in guinea pigs with antisera from day 90 .

These results suggest that the penicillin- and cephalosporin-based haptenic structures do not share structural moieties of sufficient immunochemical importance to form a basis for IgE cross-reactivity. Indeed, reports of immediate-type reactions to cephalosporins in penicillin-allergic patients are rather rare (Scholand, Tennenbaum \& Cerilli, 1968) and seem to involve mainly cephalosporins with the thiophene side-chain such as

Table V. Rast test with BPO and CEFOX in 22 patients allergic to penicillin

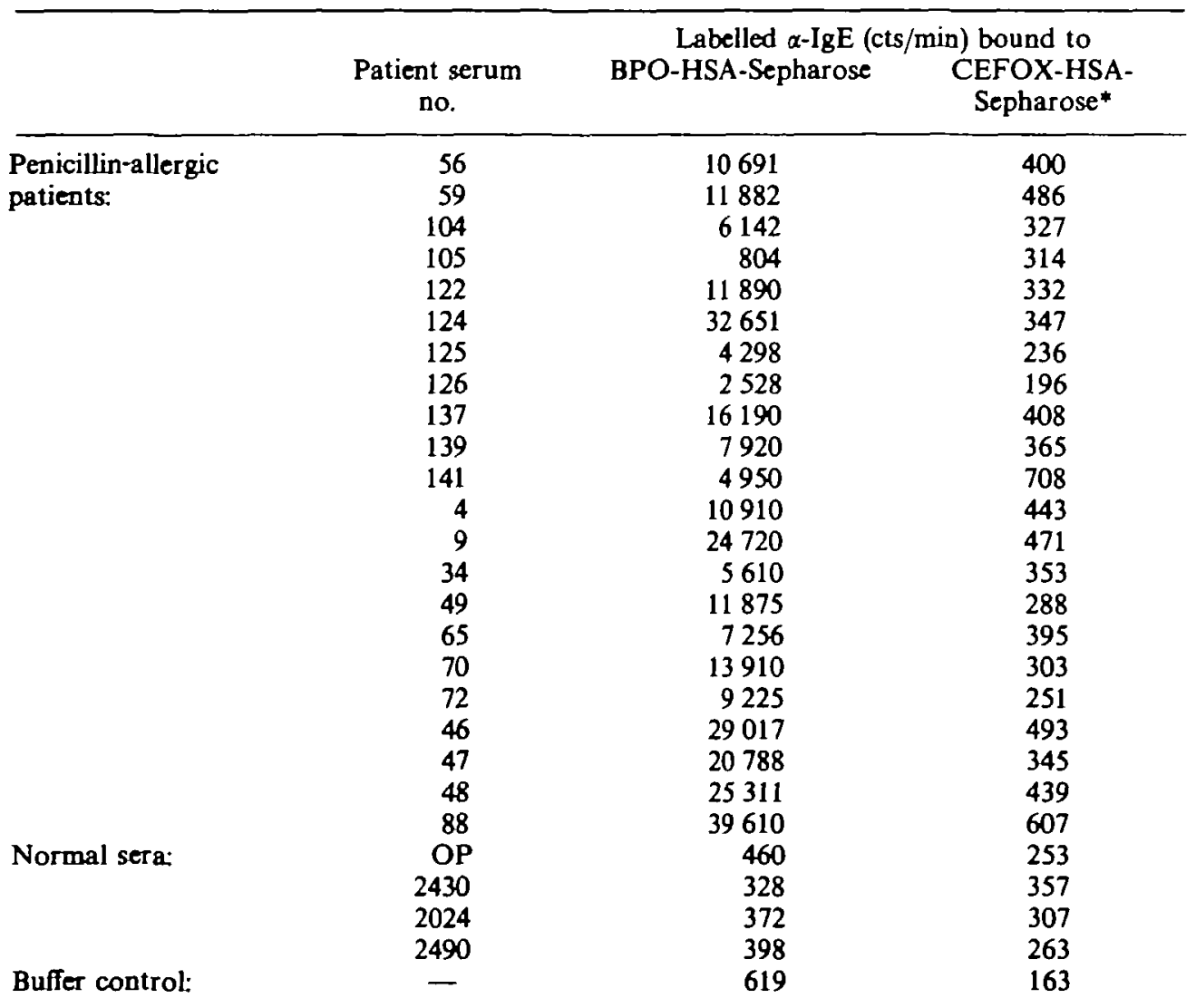

* Since we do not possess serum from a patient clinically sensitive to CEFOX as positive control, the suitability of the CEFOX-HSA-Sepharose immunosorbent was checked from its ability to adsorb guinea pig anti-CEFOX antibodies. 
cephalothin. Since the thiophene ring (Pressman \& Grossberg, 1968) is immunochemically and sterically very similar to the benzene side-chain of benzylpenicillin, and other closely related penicillins, the observed cross-reactions may be mainly due to side-chain similarity.

From our study on the specificity of antibodies raised in guinea pigs and man one would be tempted to predict that no cross-reactivity is to be expected between penicillins and cephalosporins provided the side-chains were sufficiently different in structure. This conclusion, however, has to be modified when considering the results of lymphocyte culture experiments performed with lymphocytes from penicillin-sensitized patients (Table VI). In that case, it is obvious that lymphocytes are stimulated to proliferate not only by penicillins but also by most of the cephalosporins. Indeed, both

Table VI. Lymphocyte reactivity (stimulation index) of patients allergic to penicillin

\begin{tabular}{|c|c|c|c|c|c|c|c|}
\hline $\begin{array}{l}\text { Patient } \\
\text { no. }\end{array}$ & $\begin{array}{c}\text { BPN } \\
500\end{array}$ & $\begin{array}{l}\text { AMPIC } \\
500\end{array}$ & $\begin{array}{c}\text { CEFOX } \\
100\end{array}$ & $\begin{array}{c}\text { CETAX } \\
200\end{array}$ & $\begin{array}{c}\text { CEPHALOT } \\
100\end{array}$ & $\begin{array}{c}\text { CEPHALEX } \\
10\end{array}$ & $\begin{array}{c}\text { CEPHOR } \\
20 \mu \mathrm{g} / \mathrm{ml}\end{array}$ \\
\hline 1089 & 17.5 & 27.7 & 2.4 & 1.9 & 3.4 & 0.9 & $2 \cdot 3$ \\
\hline 1098 & 22.8 & $15 \cdot 5$ & 4.6 & $7 \cdot 7$ & 1.6 & 1.5 & $2 \cdot 1$ \\
\hline 1097 & $11 \cdot 3$ & 3.0 & $2 \cdot 1$ & 2.5 & $2 \cdot 3$ & 1.4 & 1.2 \\
\hline 1101 & 97.6 & 42.0 & 5.7 & $14 \cdot 3$ & 13.6 & $1 \cdot 1$ & $10-4$ \\
\hline 1100 & $210-5$ & $56 \cdot 2$ & $8 \cdot 6$ & 7.0 & 16.0 & 0.8 & $22 \cdot 4$ \\
\hline 1103 & $20-3$ & $5 \cdot 1$ & 0.5 & 0.5 & 0.2 & 1.0 & 0.8 \\
\hline 1110 & 3.6 & 4.8 & $3 \cdot 8$ & $4 \cdot 1$ & $6 \cdot 4$ & $1 \cdot 1$ & $3 \cdot 6$ \\
\hline 1111 & 34.7 & $18 \cdot 3$ & 9.7 & $13 \cdot 4$ & $8 \cdot 6$ & $2 \cdot 6$ & 6.8 \\
\hline $1096^{*}$ & $1 \cdot 1$ & 1.2 & 1.4 & 1.6 & $1 \cdot 5$ & 0.6 & $1-0$ \\
\hline
\end{tabular}

* Non-allergic patient.

cefotaxime and cefuroxime appeared to stimulate, although to a lesser extent, lymphocytes from patients having undergone clinical allergic reactions to benzylpenicillin or to one of the semisynthetic penicillins. Accordingly, if immediate-type reactions involving antibodies, and especially IgE antibodies, will probably be very rare with cefotaxime and cefuroxime in a population of penicillin-sensitized patients, cross-allergic manifestations based on cellular reactivity such as generalized maculo-papular exanthema or fever may be expected in a sizeable proportion of cases.

In summary, cefotaxime and cefuroxime appear, at least under experimental conditions, to be less immunogenic than benzylpenicillin and semisynthetic penicillins and to be less prone to produce antibody of the $\mathrm{IgE}$ type. Cross-reactions with rodent or human IgE antibodies induced by benzylpenicillin appear to be minimal. Crossreactions may be expected, however, between cephalosporins and penicillins carrying similar side-chains. Some cross-reactivity at the level of the nucleus on the other hand has been observed with penicillin-sensitized lymphocytes. Accordingly, some crossreactivity at the level of cell-mediated allergic reactions may be expected. In comparison to some other cephalosporins, cefotaxime appears to be less toxic for the lymphoid cells and macrophages required for immune defences.

\section{References}

Dewdney, J. M. Immunology of the antibiotics. In The Antigens, Vol. IV (Sela, M., Ed.) Academic Press, New York (1977), pp. 74-245. 
Hamilton-Miller, J. M. T., Newton, G. G. F. \& Abraham, E. P. Products of aminolysis and enzymic hydrolysis of the cephalosporins. Biochemical Journal 116: 371-84 (1970)

Pressman, D. \& Grossberg. A. L. The Structural Basis of Antibody Specificity. Benjamin, New York (1968), pp. 50-2.

Stemberger, H. \& Wiedermann, C. Untersuchungen über die Bindung von Cephalosporin-CAntibiotica an Eiweiss. Zeitschrift Immunitätsforschung und experimentelle Therapie 140. 43-9 (1970).

Scholand, J. F., Tennenbaum, J. I. \& Cerilli, G. J. Anaphylaxis to cephalothin in a patient allergic to penicillin. Journal of the American Medical Association 206: 130-3 (1968). 